\title{
On the Ethical Aspects of so-called Self-Plagiarism: Or the Technology of Processing the Academic Recyclate ${ }^{1}$ Dominik Opatrný
}

In 2001 a study analysing 660 papers published in three prestigious surgical journals disclosed a disturbing phenomenon: $10.6 \%$ of the papers were duplicate studies fully or almost identical with another published text. ${ }^{2}$ The academic community is quite unanimous in that such practice is merely the result of the pressure for publication as it has developed in the natural sciences and medicine. ${ }^{3}$ This pressure is concisely expressed by the English saying "publish or perish", which could be translated into Czech as "write or wither". ${ }^{4}$ That is why certain more or less accepted rules have evolved in these fields allowing to distinguish fair use of own work from self-plagiarism. ${ }^{5}$

Czech scientometrics have subjected the humanities to a similar pressure. ${ }^{6}$ In my paper I will show that the humanities can look to the natural sciences for inspiration concerning self-plagiarism, but only to a limited extent because they lay greater emphasis on text originality.

\section{Plagiarism, the exemplar of self-plagiarism}

The essence and danger of self-plagiarism can best be seen in comparison to its "exemplar", plagiarism. The word "plagiarism" is used to signify the use of the work of another without proper citation. The word itself originates in the Latin plagio, meaning "kidnap". ${ }^{7}$ The plagiarist does not kidnap the author but his data, ideas, or words.

Let us begin with an example. In 1907 the journal Časopis katolického duchovenstva published an extensive study by the professor Richard Špaček from Olomouc "The Fourth Gospel in Protestant Scholarship" ${ }^{8}$ It is a work of admirable range. Unfortunately most of the text is

1 The study was prepared with financial support of the Czech Science Foundation, grant "History and interpretation of the Bible", no. P401/12/G168.

2 Cf. Moshe SCHEIN - Ramesh PALADUGU, Redundant Surgical Publications: Tip of the Iceberg?, Surgery 6/2001, pp. 655-661. A similar study in urological journals is more favourable, perhaps because they serve a smaller group of readers: Kiara K. HENNESSEY et al., Duplicate publications: A sample of redundancy in the Journal of Urology, Canadian Urological Association Journal 3/2012, pp. 177-180.

3 Besides the two papers cited above cf. e.g. Patrick M. SCANLON, Song From Myself: An Anatomy of Self-Plagiarism, Plagiary 2007, pp. 57-66.

4 The only reliable way of preventing self-plagiarism is therefore a change in the evaluation of research, which is not probable in the near future. Cf. Emanuela CARBONARA, Self-Plagiarizing Prostitutes: Limiting the Need to Repeat Oneself? - A Comment "On the Right to Repeat Oneself" by Andries Nentjes, Homo Oeconomicus 3/2012, pp. 441-448.

5 In the natural and social sciences self-plagiarism is closely linked to so-called "salami publications", which publish one research divided into a maximum number of papers. Since this practice is not common in the humanities I will not pay further attention to it. In my experience as editor of a theological journal authors rather struggle with studies expanding to the dimensions of small monographs. The publisher then tries to persuade them to create several separate papers or publish a book.

6 In this paper I do not wish to enter the debate whether the humanities (e.g. theology) are a science or not. I respect the contemporary dominant English terminology which restricts the word "science" to fields based on measurement, experiment and empirical data. Cf. Kundu ABHIJIT - Pramod K. NAYAR, The Humanities: Methodology And Perspectives, New Delhi: Dorling Kindersley, 2009, pp. 2-7.

7 This little witnessed word can be found e.g. in Charlton T. LEWIS - Charles SHORT, A New Latin Dictionary, New York: Clarendon Press, 1891, p. 1383.

8 Richard ŠPAČEK, Čtvrté evangelium v protestantském bádání, ČKD 3, 5, 6, 7+8, 9, 10/1909, pp. 223-229, 348-354, 411-417, 489-498, 
translated from four German publications. ${ }^{9}$ Several pages at a time are taken over without notifying the reader in an intelligible manner. If Špaček published his study a hundred years later, he would cause a small tempest. The German authors would sue him for infringing on authors' rights. The Board for Research, Development and Innovation would delete the entry from the RIV database. The Czech Science Foundation would refuse to accept the study as a grant outcome. Časopis katolického duchovenstva would publish a so-called retraction, i.e., a statement that it retracts the paper. The media would inform of the underhand practices at theological faculties and other theologians would distance themselves from Špaček... Fortunately for Spaček nothing of the sort happened, which shows how the times have changed. Today we are more sensitive to plagiarism than we were a hundred years ago. ${ }^{10}$ Why is that so?

The very name of the offence suggests that plagiarism harms the real author, who is overshadowed by the plagiarist and loses recognition, the merit for a successful experiment or a poignant formulation of an idea, and of course also the citations needed for academic advancement. The question remains open, however, if a plagiarist from among the students can cause such damage to a professor. ${ }^{11}$

But even if there was no real damage to the author, there can be real unfair self-enrichment of the plagiarist. ${ }^{12}$ The borrowed text helps the student get a degree, embellishes the academic's $\mathrm{CV}$ and perhaps even aids grant task completion. Of course it also depends on how much text or data the author used without proper source citing and whether her work would be acceptable with correct citing.

If admitting the extent of dependence would make the work unacceptable, it would be a fraud. In this there are a number of damaged parties: the tax payers who have paid for the fictitious research; the colleagues from the field against whom the plagiarist gained unfair advantage; the publisher who normally wants to publish only new findings; and finally the reader who (with some degree of overstatement) enters an implicit contract with the author that she is really the author of the text. ${ }^{13}$

Such redundant publication further devalues the work of editor, reviewers and all those who participate in the printing. I know from experience that there is nothing more depressive for editors than when the author indicates that the paper is not being published to be read, but because it "must be published". ${ }^{14}$ The last damaged party is then scholarship itself. The literature is silted with repeating the same, printing paper and readers' time is wasted. A scholar who

\footnotetext{
598-601, 644-650.
}

9 On the German sources and Špaček's possible motives cf. Dominik OPATRNÝ, Richard Špaček o Janově evangeliu: Kapitola z dějin české biblistiky, Studia theologica 4/2014, pp. 182-191.

10 Change in sensitivity to various kinds of behaviour has been described in ethics many times. Cf. e.g. Helmut WEBER, Všeobecná morální teologie, Praha: Zvon; Praha: Vyšehrad, 1998, pp. 266-268; Jindřich ŠRAJER, Pokles vědomí viny a hříchu - perspektivy teologické etiky, Studia theologica 2/2009, pp. 61-68, esp. 63-64.

11 Here I speak only of real damage. Of course, this need not necessarily be directly proportionate to the emotional response. E.g. theft usually evokes a much greater psychological reaction than loss of the same thing, because it is perceived as attack at person. This aspect is strongly present in plagiarism, but absent in self-plagiarism.

12 This also often happens in the sphere of authors' rights when someone uses a work they would not buy for the price it is offered at. On certain conditions such behaviour can even be profitable for the author, as when due to piracy the operation systems by Microsoft gained a dominant position in markets with low purchasing power and later, as their standard of living grew, the inhabitants were forced to start buying licences. As a result of piracy the competing operation system Linux eventually lost.

13 Cf. Miguel ROIG, Plagiarism and self-plagiarism: What Every Author Should Know, Biochemia Medica 3/2010, pp. 295-300. Here on the continent such description of relationships sounds somewhat strange, but in Anglo-American philosophy implicit social contract has a longstanding tradition. On the development of this tradition and its criticism on the continent cf. e.g. David BOUCHER et al., The Social Contract from Hobbes to Rawls, London: Routledge, 1994.

14 This attitude does not appear only in the Czech Republic, cf. Liviu ANDREESCU, Self-Plagiarism in Academic Publishing: The Anatomy of a Misnomer, Science and Engineering Ethics 2013, pp. 775-797, at 785: "academics appear more concerned to get published than to get read." 
wishes to find her way around the topic must uselessly go through the text to find out that it contains nothing new.

This brief overview shows that a plagiarism cannot be reduced to mere theft. Even though it is a theft, it brings along a number of other negative phenomena, perhaps even more serious ones. ${ }^{15}$

To what extent can the above analysis be transposed to self-plagiarism? Self-plagiarism is a kind of plagiarism in which the author copies her own text. Is that not a contradiction? Leaving aside special cases such as insurance hoaxes, one cannot rob oneself. In Aristotle's words "it is always necessary that justice and injustice take place among several persons... if [someone] did injustice to himself, he would suffer and do the same."16 The first mark of plagiarism is therefore absent. But in other respects the situation is different.

The author can unjustly enrich herself if unadmitted repeated use of own work brings her unjustified benefit. She can overrate the results of her grant task or improve her bibliography. But she can also annoy the reader who suddenly finds that he has already read this somewhere... Reservations can also be raised by editorial boards, whether the one where the text was sent the second time because it is only interested in publishing new texts; or the one which published it first because it can still have copies in stock. ${ }^{17}$ Finally scholarship itself suffers whether the text is copied from own work or the work of another - the literature is always silted with that.

The overall verdict therefore cannot be positive for self-plagiarism. Of course, it is not a theft and using this term is therefore in contradiction to its etymology. The author presents her words and her ideas. But there is nonetheless a certain similarity to plagiarism: the text has already been published elsewhere and the author receives credit for the same work. And so this pejorative name has found its place in publication ethics. ${ }^{18}$

When using it one needs to be careful. Not every reprinting or using a part of a text is plagiarism. It is e.g. generally regarded as legitimate when an author publishes her paper in translation or in an anthology or collection. ${ }^{19}$ Even that ought to be done according to certain rules, though. The International Committee of Medical Journal Editors recommends that authors do not try to publish the same text in several journals at once (concurrent publication). ${ }^{20}$ The editorial board cannot find out that it is a case of duplication and could feel deceived. Authors

15 In this context it is interesting how authors' rights are perceived by American law, which ever stronger influences legal systems all around the world. Contemporary American society, massaged by the publishing industry, views authors' rights as property in general. But the original idea was that the state grants some sort of monopoly to the author for some time. Such view best corresponds to the peculiar character of an author's work, such as the possibility to make copies etc. Cf. Patrick M. SCALON, Song From Myself: An Anatomy of Self-Plagiarism, Plagiary 2007, pp. 57-66, at 66, note 1.

16 ARISTOTLE, Nicomachean Ethics 1138a. Or also 1134b: "That is why we cannot be unjust to ourselves."

17 Here authors' rights can also be at stake, if the author granted their execution to the publisher by contract. But even if she did not, repeated publication before stock is sold out contradicts the publisher's interests and ought to be consulted with them.

18 Cf. Patrick M. SCALON, Song From Myself, p. 63. But this analogy [robbing oneself] is strained in the case of self-plagiarism, because the matter is not confined to theft alone but also includes imposture, in this case the presentation of material as original when it is not, even if it was original with the current author.

19 Cf. (C) The University of Queensland, Responsible Conduct of Research (on-line), at: https://ppl.app.uq.edu.au/content/4.20.02responsible-conduct-research, retrieved October $15^{\text {th }}, 2014$. Most often these are collections comprising papers on one topic published over a longer period of time. E.g. in the early stages of his career Richard Bauckham intensively devoted himself to the Book of Revelation. Before embarking on other topics he published his studies collectively under the title The Climax of Prophecy, London: T\&T Clark, 1993.

20 C International Committee of Medical Journal Editors, Recommendations for the Conduct, Reporting, Editing, and Publication of Scholarly Work in Medical Journals. Updated December 2013 (on-line), at: http:// www.icmje.org/icmje-recommendations.pdf, retrieved October 20 ${ }^{\text {th }}$, 2014. Some editorial boards expressly ask for a statement ruling out duplicate publication, e.g. Journal of Biblical Literature requires that authors submit a "a statement certifying that the article is not being submitted simultaneously to another journal. Articles that have appeared or are to appear elsewhere, or whose substance has appeared or will appear in print, whether in English or in another language, should not be submitted." Journal of Biblical Literature, Instructions for Authors $2.2 \mathrm{~b}$ ). 


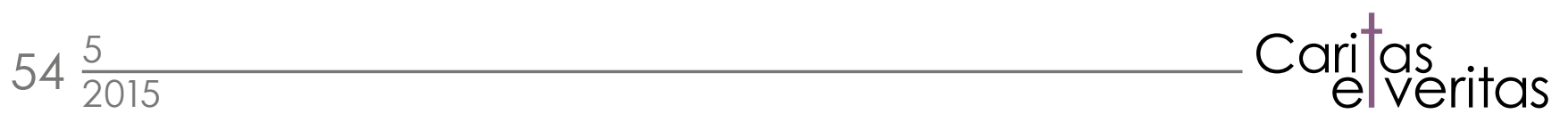

should also inform the editors of all their older works on the topic so that the editors can decide for themselves whether it is a duplicate study or not. ${ }^{21}$ Repeated publication of own text further requires consent of the original publisher of the study who can stipulate the time after which the text may be reprinted. Re-edition should be done for compelling reasons, e.g. addressing a different target group. ${ }^{22}$ In the text the author must inform the reviewers, readers and relevant authorities (the citation database, Index of results information etc.) that it is a reprint. These rules constitute a certain minimum of honesty, which should be met when re-publishing not only medical studies, but all scholarly works.

The situation becomes more complex when the author decides to use only a part of her paper. There is rivalry among scholars and an accusation of self-plagiarism can easily be abused. It is therefore necessary to stipulate what use of own text is acceptable and what is beyond the limits.

\section{Fuzzy limits}

The disciplinary commission of a humanities faculty was recently obliged to solve an unusual case: accusation of self-plagiarism of a seminary paper. In discussion two important circumstances came up. First, that year the students were expected to submit about twenty such papers. That strikingly reminds of the pressure for publication to which academics are subjected. Second, some teachers allowed "recycling" older texts if they met their requirements. The rules were therefore not uniform, which was confusing for the students. It is most desirable to eliminate such lack of clarity, especially for qualification theses. If clear rules are set for them they can be applied mutatis mutandis to seminary papers, unless the teacher explicitly states otherwise.

In general the principle holds that two degrees may not be obtained for one thesis. ${ }^{23}$ Member of Parliament Marek Benda had to give up the title JUDr. when it turned out that he had submitted his diploma thesis at the doctoral proceedings. On the other hand, the amount of text third level students must produce is growing steadily. Besides the original dissertations there are now master's thesis, the basic study has become structured (bachelor's degree has been added), theologians must write licentiate theses, not to mention an indeterminate number of seminary papers. To complete the whole course of study (doctorate) it is generally necessary to write three qualification theses with growing quality. If each of them were to be on a different topic the student would have to specialize in three spheres in turn. And here common sense warns: Is the less not in fact the more here? Is it not better to build on previous work and penetrate deeper into the problem, rather than start from the scratch each time? In other words, the question suggests itself whether it is possible to develop a previous qualification thesis in a subsequent one.

21 Informing the editorial board and readers is essential for assessing the ethical aspect. It is clearly expressed by Ian NORMAN - Peter GRIFFITHS, Editorial: Duplicate Publication and „Salami Slicing“: Ethical Issues and Practical Solutions, International Journal of Nursing Studies 2008, p. 1257: "Duplicate publication which is covert is clear scientific misconduct. A passing reference is not sufficient."

22 The usual example is a study relevant for several fields. But at the time of electronic databases it is easy to search for relevant papers from related fields (cf. Moshe SCHEIN - Ramesh PALADUGU, Redundant surgical publications, p. 658). For the Czech milieu it is interesting that the recommendation admits the possibility to print a paper which is to be published in a conference proceedings volume. Czech authors sometimes express the wish to publish in journals texts that had earlier been printed in proceedings volumes or other uncredited publications. But the editorial boards of journals, which are mostly unprofitable, cannot redress all shortcomings of Czech scientometrics. Their interest is to be the first to publish texts, if not the only ones.

23 Thanks to the legal obligation to publish qualification theses on the internet it is now easy to verify whether a student had not obtained another degree for the same work. Unfortunately it is impossible to rule out that the work had previously been submitted at a higher vocational school, since the publication obligation does not apply to them. 
None of the twenty six Czech public third level schools addresses of this issue in its study and examination regulations. ${ }^{24}$ Only the University of South Bohemia states that it is impossible to obtain two degrees for one thesis. ${ }^{25}$ No public third level school has therefore so far decided to proceed uniformly in the matter of "recycling" qualification theses. If students want to learn what they can and cannot do, they can look for information in faculty materials from dean's guidelines to various instructions published at department websites. In such inconsistent environment students and anybody else will find it difficult to get around.

Let us therefore try to take a look at a particular segment, at theological faculties. These also usually do not stipulate the conditions of using own work in dean's guidelines or methodological instructions. ${ }^{26}$ The only exception is the Doctoral proceedings regulations of the Sts Cyril and Methodius Faculty of Theology of the Palacky University, which reads: "Only a reworked thesis, which can be content-identical with the original work to the maximum extent of $50 \%$, can be presented as changed bachelor's, master's, dissertation, or associate professor thesis defended according to the law." ${ }^{27}$ It therefore allows that a participant in doctoral proceedings half recycles an older work.

This overview has shown that instructions for use of own text can be looked for only in dean's guidelines or even lower norms and recommendations - and even there will be very few. Let us therefore now take a look at several other searchable examples. The manual for writing master's theses at the Department of Psychology FF UP allows that a master's thesis contains at most $50 \%$ of bachelor's thesis. ${ }^{28}$ On the other hand, the Department of Experimental Plant Biology of PF UK in instruction for students expressly bans using even a part of the text of a bachelor's thesis in a master's thesis. ${ }^{29}$ Two other schools allow recycling one third of a bachelor's thesis, or $30 \% .^{30}$ Internal instructions of third level schools therefore leave the answer mostly up to the supervisor. In fact it is the committee at the defence proceedings who has the last say. In this way the student falls into legal insecurity.

The last limit mentioned, $30 \%$, without doubt originates in the unwritten rule spread among scholars themselves according to which a paper can contain up to $30 \%$ older texts. ${ }^{31}$ No one

24 The information was verified for May $11^{\text {th }}, 2015$.

25 Cf. JIHOČESKÁ UNIVERZITA, Studijní a jednací řád Jihočeské univerzity v Českých Budějovicích ze dne 24. čerona 2014, art. 30, § 8. A similar instruction of Palacký University forbids plagiarism, which it defines as conscious direct or indirect recourse "to published or unpublished work, part of work or expressed idea of another with the intention of making the impression that it is the author's own work or idea," UNIVERZITA PALACKÉHO, Úplné znění studijního a zkušebního ř́du Univerzity Palackého v Olomouci ze dne 9. července 2013, art. 26, § 3.

26 For CMTF UP: Směrnice děkanky, kterou se stanoví podrobnosti k provedení Studijního a zkušebního řádu UP na CMTF UP, Řád pro studium v doktorském studijním programu na CMTF UP; for TF JU: Tomáš VEBER - Petr BAUMAN, Metodická pomůcka ke zpracování závěrečných prací, České Budějovice, 2010, Opatřeni děkana k realizaci státních závěrečných zkoušek v bakalářském, magisterském a navazujícím magisterském studiu na TF JU, Opatření děkana č. 127 k prübèhu státní doktorské zkoušky a obhajoby disertační práce na TF JU, Opatření děkana č. 157 k prüběhu státní doktorské zkoušky a obhajoby disertační práce na TF JU; for KTF UK: Pravidla pro organizaci studia KTF, Opatření děkana k Pravidlüm pro organizaci studia, Metodická pomůcka ke zpracování závérečných prací; for HTF UK: a series of dean's measures for final state examinations and rules of doctoral study, for ETF UK: Pravidla pro evidenci, odevzdávání a zveřejňování závěrečných prací, Manuál k formálním náležitostem akademických písemných prací.

27 CMTF UP, Řád rigorózního ř́zení na CMTF UP, art. v., § 2.

28 Cf. FF UP, Manuál pro psaní diplomových prací na katedře psychologie FF UP, Olomouc, 2011, p. 46. Similarly the doctoral proceedings regulations of Palacký University allow that a doctoral thesis contain up to $50 \%$ of master's thesis (Univerzita Palackého, Řád rigorózního rízení, Olomouc, 2013, art. 6, point 2). For other works the Study and examination regulations do not stipulate any such rule.

29 Cf. @ Katedra experimentální biologie rostlin, Přírodovědecká fakulta UK, Diplomové práce, (on-line), at: http://kfrserver.natur.cuni.cz/ studium/diplom-pozadavky.html, retrieved October $20^{\text {th }}, 2014$. The Faculty of Pedagogy UP requires self-citation if the student uses data from her bachelor's thesis in her master's: Katedra antropologie a zdravovědy PdF UP, Doporučená kritéria pro psaní bakalářských a diplomových prací na Katedře antropologie a zdravovědy PdF UP v Olomouci, Olomouc, 2012, p. 3.

30 Cf. PRAŽSKÁ VYSOKÁ ŠKOLA PSYCHOSOCIÁLNÍCH STUDIÍ, Bakalářská a diplomová práce. Informativní text pro studující Bc. a NMgr. studia, Praha, 2012, p. 3; FAKULTA SPORTOVNÍCH STUDIÍ MASARYKOVY UNIVERZITY, Pokyny k vypracování závěrečné (bakalářské/diplomové/rigorózní) práce, Brno, 2013, p. 2.

31 Cf. Pamela SAMUELSON, Self-plagiarism or fair use? Communications of the ACM 8/1994, pp. 21-25. A passionate defence of the right to repeat oneself, including an accusation of publishers of creating cartels promoting their private interests under the disguise of fighting selfplagiarism, can be found in Andries NENTJES, On the Right to Repeat Oneself, Homo Oeconomicus 3/2012, pp. 413-431. But even if we granted 
ever officially promulgated this rule but some authors have decided to adhere to this limit themselves. ${ }^{32}$ This can be explained so that one can repeat the section "methods", but not "results" and "discussion". It seems therefore that this limit was introduced by natural and social scientists, from whom it then spread to other fields.

Publishers, on the other hand, have much stricter requirements. Either they ask absolutely new texts from contributors, or they admit a lesser degree of agreement. In 2011 Yuehong Zhang and Xiaoyan Jia conducted research in 219 scholarly journals. ${ }^{33}$ Although they researched primarily attitudes to plagiarism, several questions also had bearing on self-plagiarism. It turned out that $81 \%$ editors would reject or return for supplementation a paper in whose results and conclusion sections the author recycles his texts, even if it were innovative.

From these results yet another thing follows. Editors require different measure of originality for different parts of the work. Originality of data, which natural and social sciences take stand on, is a matter of course. ${ }^{34}$ Strictest criteria will therefore be applied to the sections "results" and "discussion", whereas the section "methods" can according to 71\% respondents contain up to one fifth of uncited text of another author (sic!) (for reasons see below). ${ }^{35}$ The percentage expression is therefore only a rough guideline, it also matters which section of the paper a text comes from.

\section{And how about the humanities?}

The attentive reader will have noticed that the description above concerns a very different kind of texts than she is used to in the humanities, since the natural and social sciences differ from the humanities not only in their methodology, but also in the literary genre of the scholarly publications they produce.

How can the literary genre of natural and social science papers be described? They are based on research (in a narrow sense of the word) and ought to present the measured data as precisely as possible. Ideally they could be expressed only by means of the universal formal language: mathematics. ${ }^{36}$ But that alas (or thank God) is not sufficient for the human brain. That is why

this right to authors, do they have the right to draw public funds for their repetitions? And is it not deceptive if they do not inform readers and editors of this?

32 Marie Macková even states that if a reworked publication differs by one quarter of text from the original one, it is already a new text which can be declared as a new publication (she does not discuss the rights of the original publisher in this case). Unfortunately she does not back this claim by any reference to literature, so it is again some sort of unwritten rule. Cf. Marie MACKOVÁ, Etika publikování - quo vadis?, Aktuální otázky sociální politiky - teorie a praxe 1/2013, p. 28. Knecht and Dvořáček distinguish between duplicate publication of the whole paper (whether the agreement is verbatim, significant, or in the form of paraphrase) and recycling bits of own texts. While they unambiguously condemn the former, they regard the latter as "ethically doubtful". The question remains where doubtful recycling ends and forbidden paraphrasing begins. The magical limit of 30\% appears here too. Instead of the amount of recycled text it here stipulates the maximum amount of self-citations on the literature list. Cf. Petr KNECHT - Dominik DVOŘÁK, Etika vědecké práce a publikování pro mírně pokročilé, Pedagogická orientace 4/2013, pp. 566-568.

33 Yuehong ZHANG - Xiaoyan JIA, A Survey on the Use of CrossCheck for Detecting Plagiarism in Journal Articles, Learned Publishing 4/2012, p. 298. Another survey is reported by Kravitz and Freedman who found in an informal questionnaire that many scholars are willing to accept $10 \%$ recyclate, several 15-20\% and none more than 30\% - Richard L. KRAVITZ - Mitchell D. FELDMAN, From the Editors' Desk: Self-Plagiarism and Other Editorial Crimes and Misdemeanors, Journal of General Internal Medicine 1/2011, p. 1. The results are unfortunately presented in this indeterminate way.

34 Here they even see a sphere where self-plagiarism can pose a risk to health. In 1997 Martin R. Tramèr described a mechanism how covert multiple publication of the same research (same data) affects doctors' opinions of the effectivity of medicaments. He compared studies measuring the effect of ondasetron on after-surgery vomiting. It turned out that duplicate studies tend to repeat more favourable results. This has consequences for meta-analysis of data: according to all published studies the medicament helps one in 4.9 patients (number needed to treat index), while in original studies it was only one in 6.4 patients. Cf. Martin R. TRAMÈR - D. John M. REYNOLDS - R. Andrew MOORE - Henry J. MCQUAY, Impact of Covert Duplicate Publication on Meta-analysis. A Case Study, BMJ 1997, pp. 635-640.

35 And according to $9 \%$ respondents even more. In the social sciences, which are closest to the humanities, this figure is only $59 \%$.

36 The popular saying that mathematics is the language of science originates in Galileo's notion that mathematics is the language of nature: 
these sciences help themselves out with our "imperfect" natural language. But the text is very much formalized, structured according to a pre-determined pattern, and presents obtained data in a form free from disturbing elements. The author herself steps back, since the ideal of the natural sciences is minimizing the observer's impact on observation. In fact copying words when describing new data would not be so bad, if it was not a theft... ${ }^{37}$

Humanities papers are of totally different character. They are not written for the purpose of publishing recorded data or interpreting them, but for deeper understanding of the investigated problem. The paper is either descriptive and corresponds to the natural scientists' review articles. In that case it brings nothing new and its value is merely didactic. Or it contains an argument. But someone must personally back that, whereby the writer becomes an author worthy of the name. ${ }^{38}$ Such author can in no way hide behind the words of another (plagiarism). At the same time she is not engaging in a monologue. We speak of scholarly discourse, i.e., of a speech current which the individual authors enter and in which they try to reach an ever better grasp of the problem and its verbal expression. In order for the current to be unitary, interaction must exist among speakers, which we call dialogue. If in dialogue we keep repeating the same, do not strive for new expressions and do not react to our partners' incentives, we will never get anywhere. ${ }^{39}$ That is why the humanities have greater antipathy to repeating words, even if they are merely "technical detail". ${ }^{40}$ The author can either simply refer to her older text, or just summarize the results she is building on.

The difference stands out even more when we consider the reader. In the natural and social sciences she needs to know an accurate description of the methodology, or instructions how to repeat the experiment or research (repeatability of experiment). Scientists from these fields justly complain that some procedures cannot be described in a new manner each time, and therefore they can repeat what others have written. ${ }^{41}$ It is like when someone is writing an instructions manual for a product that has undergone minor alterations. She will also not try to be original at all cost. The situation in the humanities is quite different. New expressions constantly incite to new rethinking on the part of both the author and the reader. The reader will more easily achieve deeper insight into a problem if she reads about it repeatedly, but slightly differently each time and from a different angle (that is why two papers ought not to have the same main idea). Simple copying of own text is therefore inappropriate, even when it is not a case of deception. But editors and colleagues should not be scrupulous when judging writers, since authors are already now burdened by pressure for publication and the requirements of reviewers, which in individual cases can be nit-picking. ${ }^{42}$

\footnotetext{
GALILEO GALILEI, Il Saggiatore, Frammenti e lettere, Livorno: Giusti, 1917, p. 6: "Philosophy [i.e., physics] is written in this great book (by which I mean the world), which we have constantly open in front of our eyes, but no one can understand it unless he first learns to understand the script in which it is written. It is written in mathematical language..."

37 This can be seen from the answer to the question how long sequence can be copied from another author without citing. The median of answers is $8-10$ words for all fields, with the exception of the social sciences which admit only one word.

38 The concept of authorship in the natural sciences deserves more in-depth elaboration. Well-known are long lists of "authors" even for relatively short texts, which rather make provision for institutional participation in financing the research than participation of persons in text preparation. It is evidently a different matter than literary authorship.

39 Of course, there is also the very effective broken record strategy. With that it is rather possible to assert oneself than find the truth. Cf. Ján PRAŠKO - Hana PRAŠKOVÁ, Asertivitou proti stresu, Praha: Grada, 2007, pp. 190-191.

40 In other words, papers in the humanities need not repeat standardized sections of text, such as description of methodology. In their text there is stronger presence of argument, which underscores the involvement of author and her own words.

41 Cf. Patrick M. SCALON, Song From Myself, p. 63

42 On the ethics of reviewing cf. Michal ALTRICHTER, Několik bodů k etice recenzování, Teologické texty 3/2006, pp. 160-161.
} 


\section{Conclusion}

The present situation, when rules for repeated use of own text are often merely implicitly assumed, is beneficial for neither scholars, nor editors. Based on the preceding analysis it is therefore possible to formulate several conclusions.

First of all, it seems to be out of the question that the humanities copy rules originating in the natural and social sciences. A research paper contains certain standardized sections, in which text repetition is sometimes necessary. But this is not the case with e.g. theological or art-theoretical papers.

The most important task is that third level schools define clear rules for elaborating one qualification thesis in another. It is necessary to stipulate the maximum level of agreement between the two texts and manner of notifying that it is an elaboration of another text. Even though percentage stipulation can appear too formal, students need to have greater legal certainty. After all, these works are only done for practice.

But we will not get by with percentage alone in the case of real scholarly texts. Even so editorial boards of journals and publishers should stipulate clearer rules in their instructions for authors than just a general statement that they accept "new and innovative studies". Reprinting a work ought to be justified and the author must unconditionally notify all concerned parties of the fact. ${ }^{43}$ As for use of other own work, editorial boards can stipulate a reference maximum level of text agreement. I believe that in the humanities it is not suitable to re-use one's own text to a greater extent than the text of another. But it is not just a matter of text. In the natural and social sciences data originality is most valued. In the humanities, on the other hand, the main argument should not be repeated, although repeating supporting ideas certainly cannot be avoided and would not be appropriate. But first of all the editorial board can require authors to consistently refer to their older relevant texts, so that the reader can get an idea of the assets of the new text. The process of accepting a paper is not an effort of the editorial board to assert its interests against the author, as some blame them of doing. ${ }^{44}$ The editorial board decides according to reviews and reviewers are recruited from the collective of authors. That is why it is sufficient that the maximum percentage of agreement be only for reference, so that in a given case the reviewer can defend a higher level of agreement in his review.

On the part of the author the most certain strategy is to consistently refer to all own older texts. Then she will avoid unpleasant misunderstandings, at worst she may be obliged to rework a part of the text. Of course, such solution is merely external and smacks of tutiorism. ${ }^{45}$ What is necessary, therefore, is always also right inner motivation. This is absent when the author regards writing as a necessary evil she must undertake in order to be able to lecture, progress up the academic ladder, or boast of a further item in her bibliography.

At present various coaches and work advisors try to help with finding the right motivation. It would be interesting if one of them addressed the question what motivation works for writing scholarly literature. She would certainly emphasize focus on reader and on the process of writ-

43 Cf. Martin R. TRAMÈR - D. John M. REYNOLDS - R. Andrew MOORE - Henry J. MCQUAY, Impact, p. 639: “The key issue here is cross referencing. Without cross referencing duplication becomes covert," and therefore fraudulent. Not any kind of reference is sufficient, but a clear statement that the data or text has already been published.

44 Cf. especially Andries NENTJES, On the Right.

45 Tutiorism is a system used in the history of Catholic moral theology, according to which a Christian is rather to adhere to the safer path and obey every law unless certain of its invalidity. More on tutiorism and its kinds see e.g. Hieronymus NOLDIN - Albert SCHMITT, Summa theologiae moralis. De principiis, Oeniponte: Rauch, 1941, pp. 229-230. 
ing itself, since we can achieve the strongest feeling of fulfilment when we offer the reader an innovative and at the same time enjoyable paper. To be able to do that we must develop not only our scholarly competencies but also literary ones. Especially the latter must be learned. Classical ethics would call such learned skills virtues. And of virtue it holds that it suffices for satisfaction, independently of results. In particular: who enjoys the game rather than winning never thinks of pressing $\mathrm{Ctrl}+\mathrm{C}$.

\section{On the Ethical Aspects of so-called Self-Plagiarism: Or the Technology of Processing the Academic Recyclate}

Abstract The so called redundant publications are becoming a major theme in the academic sphere, as it has become easier to produce and reveal copied texts. Nevertheless, the academic sphere lacks precise university regulations and journal policies distinguishing ethically acceptable recycling from unethical self-plagiarism. The article analyses several norms in their academic context. Two interesting observations are shown: first, the existing rules differ significantly; second, they originate in the natural and social sciences. I argue that more precise norms are needed. It would be, however, not possible to agree on a single set of universal rules, as they must take into consideration also the specifics of each academic discipline, especially in the case of humanities.

Keywords Self-plagiarism, Ethics, Humanities, Social sciences, Natural sciences 